\title{
Adaptive Reuse as A Strategy Toward Urban Resilience
}

\author{
Deniz Ozge Aytac ${ }^{1}$; Tulin Vural Arslan² , Selen Durak²
}

\begin{abstract}
The significance of urban development has been realized again while acute shocks and chronic stresses (earthquake or unemployment) affect cities in a negative way. Therefore, urban resilience becomes more important for economic, environmental, and social sustainability of the built environment. There is a wide range of approaches to resilience in the literature such as ecological, engineering, and adaptive systems. Unlike others, adaptive resilience establishes a co-evolutionary interaction between actors (existing building) and the system (external effects) that leads to a continual process on their adjustment. In relation to cities, built environment is also under a constant change. As the advent of new technology has changed buildings' use, some of them have faced obsolescence in physical, economic, functional, technological, social, legal, and political ways. The importance of time-based design over form-based design thinking has come to the fore. However, existing obsolete buildings could gain new functions and contribute to urban resilience and sustainability through adaptive reuse method. The purpose of this study is to provide assessment criteria for existing buildings' adaptive reuse potential in the context of resilient cities. Thus, the research incorporates Holling's resilience cycle (1986) and Schmidt III et. al' s building layers and time concept (2009) for resilient adaptive reuse strategies.
\end{abstract}

Keywords: adaptive reuse, resilient cities, adaptive resilience, building layers, time-based design

\section{Introduction}

Cities are still hubs of dwelling, production and creativity. In accordance, migration to cities is increasing every year. Therefore, the capacity of cities for accommodating the needs is being questioned. With hindsight, twentieth century modernization movement in architecture and planning caused serious consequences in the urban environment. Cities were segmented in terms of functions. Industrialization created new jobs and attracted populations to cities. With the increase in population, pollution, security and health issues, garden city movement was promoted and middle and upper class city dwellers spread out to city perimeters. Decentralization led to long term problems. For example, urban sprawl increased, motorized urban fabric emerged, social segregation became apparent, edge cities formed, urban diversity decreased, and agricultural land was wasted. Buildings in city center started becoming obsolete and under maintained. In most cases owners ignored these problems because it was expensive to repair and did not generate a financial return. In response to negative impacts of decentralization, new urbanism concept was introduced around the 1980's. Sustainable city strategies were developed. Today, it is observed that urbanization in the 21 st century is still increasing. Prevailing problems are energy, environment and social 
issues based on excessive population. Also, limited resources and their unwise consumption threaten sustainability of the cities.

In addition, twenty-first century planning and architectural practices have been affected by policies and economic activities that support "neo-liberal debt-oriented economy" (Resilience Thinking in Urban Planning, p.3). In many cases urban renewal movement demonstrates a market oriented, entrepreneurial architecture and planning decisions. In this regard, underuse old building stock is replaced with high density tall dwelling blocks or business centers. In consequence, the city's identity, authenticity and socio-economic diversity are damaged as well as its energy and resources are used carelessly. According to United Nations Habitat by 2050 population in cities will increase up to 60 percent. This will bring up accommodation and planning problems, insufficient infrastructure, and increase in energy consumption. Resilience of cities to sudden shocks and stresses will be in question. From this perspective adaptive reuse could be a strategy toward making cities resilient to future issues.

Twenty-first century's city structure is getting more complex than before. The city has branched out and become multi-nuclei entity. It consists of multiple scale systems and cycles. These systems are in constant change so does the city. Showing resemblance to living organisms, the city needs to be adaptable in the face of changing conditions. How well the city responds to these changes can be studied under the concept of resilience. Originated in ecology, resilience demonstrates stages of change. In the case of city resilience, multiple scale and continuous adaptive resilience theory becomes more suitable than ecological and engineering perspectives (Martin 2012; Dolega and CelińskaJanowicz 2015). City resilience is about how well the city could absorb shocks as well as it could function and reorganize itself when it faces destabilizing shocks and stresses. So that city dwellers survive and flourish regardless of shocks and stresses (Arup City Resilience Framework, p.3). Cities are interrelated and connected to multiple dynamic and static systems on varying levels directly or indirectly. Therefore, this complex system is open to various threats and trends. In order to strengthen city resilience, critical systems and levels should be identified and their strengths and weaknesses should be determined. In this regard, establishing city resilience is gaining importance (Collier, Hambling, Kernaghan et al., 2014, 'Tomorrow's cities: a framework to assess urban resilience', p.79).

With the predicted population wave, city resilience could benefit from adaptive reuse of the existing building stock. Adaptive reuse is a revitalization strategy that gives a new life to an existing building or structure through a new function. It is a sustainable way to create good urban environments because it keeps the existing urban fabric, requires less energy and has a lower environmental impact than a new building construction. Besides, "adaptive re-use gives new life to a site, rather than seeking to freeze it at a particular moment in time, it explores the options that lie between the extremes of demolition or turning a site into a museum. Adding a new layer without erasing earlier layers, an adaptive reuse project becomes part of the long history of the site. It is another stage, not the final outcome (Justine Clarke, Adaptive Re-use of Industrial Heritage, Heritage Council Victoria, 2013)." (ODASA Design Guidance Note 1.2.1 July 2014) Adaptive reuse strategy can benefit to the urban environment in cultural (memory, cultural value, built heritage, familiarity), ecological, energy, and environmental ways. 
This study aims to present a set of adaptive reuse criteria on the way of achieving urban resilience. As a consequence, the study combines adaptive resilience and layers concept for a detailed adaptive reuse strategy that could be used to assess existing and future building's adaptive reuse potential.

\section{Theoretical background}

In order to present an urban resilience strategy through adaptive reuse, two concepts, adaptive cycle and layers, are integrated into this study. This section will lay out how these three concepts are connected and will inform adaptive reuse as a strategy toward urban resilience.

\begin{tabular}{|c|c|c|c|}
\hline Adaptive Resilience & Layers Concept & Adaptive Reuse & \\
\hline $\begin{array}{c}\text { Adaptive Cycle } \\
\text { Holling } 1973\end{array}$ & Stewart Brand (1994) & $\begin{array}{l}\text { Existing Infrastructure } \\
\text { (Urban Fabric) }\end{array}$ & Strategy \\
\hline
\end{tabular}

Figure 1. Theoretical concept diagram of the study

\subsection{From Resilience to Adaptive Resilience}

Resilience concept is adapted to various fields such as psychology, economics, geography, physical science, planning, and disaster management. In the scope of this paper three interpretations of resilience will be analyzed. The term is originated in ecology and established by Crawford Stanley Holling's work in 1973. Inspired by ecosystems, he develops a thought model of how these systems work. He defines resilience as a measure which shows the ability of these systems to absorb and cope with the changing circumstances. In a similar manner Berkes and Folke defines resilience 'measure of robustness and buffering capacity of the system to changing conditions' (Folke et al., 2002). The system is based on absorbing shocks before getting unstable and reach to another equilibrium (Dolega \& Celińska-Janowicz, 2015, p.11-12). Second, the field of engineering concentrates on a system resistance and its rebound to previous state or path. In this framework, the system's initial status is recognized as a stable configuration. A disruption to the system will shift the growth path and it is expected that the system will restore to its previous path by self-correcting forces and adjustments (Dolega \& Celińska-Janowicz, 2015, p.12). Third, adaptive resilience system is established on complex adaptive theory that demonstrates 'self-organizing behavior and adaptive capacity', responds to destabilizing shocks with a reactive reorganization to reduce the impact. This interpretation of resilience employs a co-evolutionary interaction between actors within the system. As a result, it could absorb and reconfigure its structure for the future development (Dolega \& Celińska-Janowicz, 2015, p.13). Adaptive resilience is associated with Holling's adaptive cycle (panarchy) (1986) work which he identifies four phases of change: growth (birth/exploitation), conservation, release (creative destruction), and renewal (reorganization). He forms this cycle as infinity symbol (sideways eight) to represent systems on different scales (Gunderson \& Holling, 2002 as cited in Davoudi, Boorks, Mehmood, 2013, p.310). Cities represent more likely adaptive cycle of resilience since they change continuously based on economic, social, political, planning point of view and do not restore to their previous condition (Barata-Salgueiro \& Erkip, 2014). 
Table 1. Resilience concepts and qualities (adapted from Dolega et.al. 2015)

\begin{tabular}{|l|ll|}
\hline Resilience Concepts & Qualities \\
\hline $\begin{array}{l}\text { Engineering Resilience } \\
\text { (physical sciences) }\end{array}$ & - & $\begin{array}{l}\text { One equilibrium in stable state (a property or a characteristic) } \\
\text { Restore to previous condition after disruption/shock }\end{array}$ \\
\hline $\begin{array}{l}\text { Ecological Resilience } \\
\text { (ecological sciences) }\end{array}$ & - $\begin{array}{l}\text { Multiple equilibriums but stable } \\
\text { System can absorb shocks before destabilized, then move to } \\
\text { another equilibrium state }\end{array}$ \\
\hline $\begin{array}{l}\text { Adaptive Resilience } \\
\text { (complex systems theory) }\end{array}$ & - $\begin{array}{l}\text { A process (not a state) } \\
\text { - System can absorb the shock }\end{array}$ \\
& $\begin{array}{l}\text { Spontaneous / anticipatory / reactive reorganization / self- } \\
\text { Organizing behavior }\end{array}$ \\
\hline
\end{tabular}

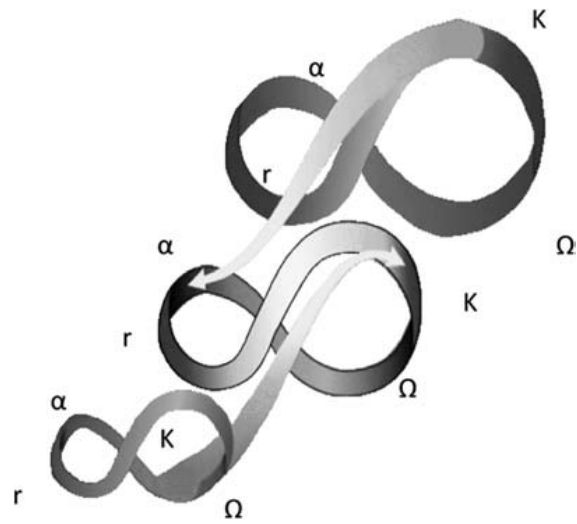

Figure 1. Adaptive cycle diagram (Source: Holling and Gunderson, 2002)

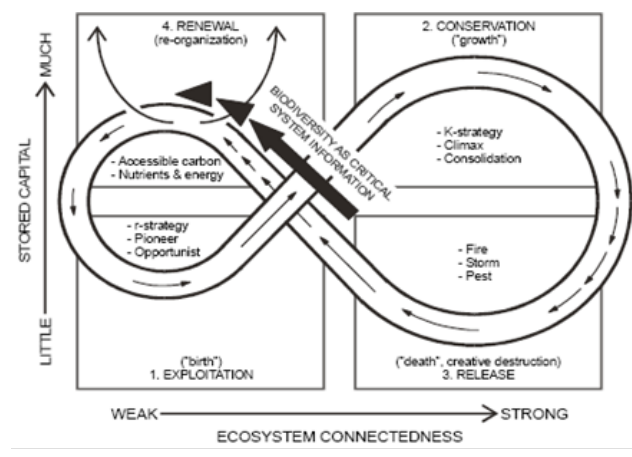

Figure 2. Phases of adaptive cycle (Source: Holling and Gunderson, 2002)

\subsection{Building Layers in Relation to Adaptive Resilience}

Built environment is under constant change in relation to internal and external causes. Due to these effects, buildings might face with various obsolesces in time. Buildings consist of components that vary in shape, life-cycle, or operation. These parts react to the effects in different ways and times. In consequence, implementing time based thinking over form based thinking is desirable and suitable for the built environment. Schmidt III et.al. (2009) asserts that time and layer integrated adaptability is an important design characteristic of buildings (Schmidt III, 5-9 October 2009). Adaptability is the capacity of the building to be able to alter in order to react and be compatible of developing changing demands and 'maximizing value throughout its lifecycle.' Buildings respond to changing conditions because of their dynamic qualities. This is possible through how they are in contact with evolving external and internal causes that require them to adapt changes over time. Another characteristic that buildings are affected to change is layers. Buildings are composed of levels that absorb and respond to changes in varying time and functions. Layers concept was introduced in John N. Habraken's work (1988), namely urban structure, tissue, building, infill and furniture, as decision making 
levels (Open Building concept) and principle of spatial organization (Habraken, 1988). In 1994, Stewart Brand claimed that the built environment adapts, changes and he brought forward 'shearing layers' concept from quickest to slowest change, stuff, space plan, services, skin, structure, and site. Besides levels, Brand also denoted how frequently a layer could change. Schmidt III et. al. has expanded this study by adding adaptable strategies, type of change, and frequency of change.

Table 2. Building Layers (adapted from Schmidt III et.al. 2009)

\begin{tabular}{|c|c|c|c|c|c|c|}
\hline \multicolumn{3}{|c|}{$\begin{array}{l}\text { Building Layers and Time } \\
\text { (Stewart Brand 1994) }\end{array}$} & \multicolumn{4}{|c|}{$\begin{array}{l}\text { Adaptable Strategies and Layers } \\
\text { (Schmidt III et.al. 2010) }\end{array}$} \\
\hline Layer & Description & Timescale & Strategy & $\begin{array}{l}\text { Type of } \\
\text { change }\end{array}$ & $\begin{array}{l}\text { Building } \\
\text { layer(s) }\end{array}$ & $\begin{array}{l}\text { Frequency } \\
\text { of change }\end{array}$ \\
\hline Site & $\begin{array}{l}\text { Geographic setting } \\
\text { of building }\end{array}$ & Eternal & Moveable & $\begin{array}{l}\text { Change of } \\
\text { location }\end{array}$ & $\begin{array}{l}\text { Structure, } \\
\text { Site }\end{array}$ & Low \\
\hline Structure & $\begin{array}{l}\text { The load bearing } \\
\text { elements including } \\
\text { foundations }\end{array}$ & $\begin{array}{l}30-300 \\
\text { years }\end{array}$ & Scalable & $\begin{array}{l}\text { Change of } \\
\text { size }\end{array}$ & $\begin{array}{l}\text { Space, } \\
\text { Services, } \\
\text { Skin, } \\
\text { Structure }\end{array}$ & $\begin{array}{l}\text { Moderate / } \\
\text { Low }\end{array}$ \\
\hline Skin & $\begin{array}{l}\text { The exterior } \\
\text { surfaces that } \\
\text { provide a weather } \\
\text { protecting layer }\end{array}$ & 20 years & Convertible & $\begin{array}{l}\text { Change of } \\
\text { function }\end{array}$ & $\begin{array}{l}\text { Space, } \\
\text { Services, } \\
\text { Skin }\end{array}$ & Moderate \\
\hline Services & $\begin{array}{l}\text { The working guts } \\
\text { of a building }\end{array}$ & $\begin{array}{l}7-15 \\
\text { years }\end{array}$ & Refitable & $\begin{array}{l}\text { Change of } \\
\text { performance }\end{array}$ & $\begin{array}{l}\text { Space, } \\
\text { Services, } \\
\text { Skin }\end{array}$ & Moderate \\
\hline $\begin{array}{l}\text { Space } \\
\text { Plan }\end{array}$ & The internal layout & $\begin{array}{l}3-30 \\
\text { years }\end{array}$ & Versatile & $\begin{array}{l}\text { Change of } \\
\text { space }\end{array}$ & Stuff, Space & High \\
\hline Stuff & $\begin{array}{l}\text { Furniture, } \\
\text { equipment }\end{array}$ & Daily & Adjustable & $\begin{array}{l}\text { Change of } \\
\text { task }\end{array}$ & Stuff & High \\
\hline
\end{tabular}

\subsection{Adaptive reuse}

Adaptation of existing buildings for new uses is gaining importance in sustainable point of view (Bullen \& Love, 2011). The major reason is that converting existing building stock for a new use facilitates to sustainable development in three ways: it is less expensive than demolish and rebuild a new one, requires less energy and resource consumption, and is a way to sustain familiar urban fabric, memory places and landmarks. Adaptive reuse is a revitalization strategy for the urban environment that uses a link of actions, namely 'plan, inventory, acquire, manage and reuse surplus or abandoned real estate' (Burchell and Listokin, 1981, as cited in Wilson, 2010). When a previously inhabited land or building has become obsolete, adaptive reuse is a strategy to increase the site's potential value in aesthetic, structural, and characterful ways (Burchell and Listokin, 1981, as cited in Wilson, 2010). Buildings are exposed to human and/or environment related internal and external effects. These effects lead to obsolescence in the building. There are six obsolesce types identified by Langston et.al. (2007). Physical deterioration negatively affect buildings' physical performance during time and lead to physical obsolesce. When the property falls from its economic value and does not attract 
investors for business, it is affected by economic obsolescence. Once business purposes are changed and building does not respond to functional needs, functional obsolesce occurs. With the rapid change in technology, buildings are needed to be updated in order to have energy efficiency and low operational costs. Changes in the society happen more frequently than in the buildings. So, buildings might become outdated and need for a change in terms of aesthetics. Legal obsolesce occurs when revised regulations could lead buildings to be updated to comply with them (Langston, et.al. 2007).

According to Loures and Panagopoulos (2007), successful adaptive reuse projects should combine five principles: fulfill the purpose of redesigned function, endure for a long time and adapt to new uses, react well and improve the quality of its context, be visually coherent and pleasurable for users as well as passers-by, and have sustainable qualities (Wilson, 2010, p.4). Besides, Australian International Council on Monuments and Sites (ICOMOS) Burra Charter outlines seven principles that will help to deliver successful adaptive reuse projects. First one is creating a collaborative and multi-disciplinary design team that will help strategic planning, implementation and bring multi-professional approach to design. Second, engaging with stakeholders reveals views, likes/dislikes and creates sense of ownership and involvement for the community. Learning from other projects could gain valuable perspective for professionals in the project about creativity, regulations, post-occupancy evaluations. Next, making most of the existing conditions can be established through careful studies of the site, urban fabric, and users. Time based thinking is about phasing the project out, so that a successful redesign takes in place. Maintaining the quality throughout the project positively affects the long term maintenance and use. Finally, life-cycle costing is working with investors and contractors on financial model of the design so that the design is implemented successfully and returns the investment in the long run (ICOMOS, 2014, p.5).

Measuring adaptive reuse potential of a building will reveal constraints, opportunities, and lead to successful future adaptation of the building. There are two studies about adaptive reuse potential assessment in the literature. 'Adaptive Reuse Potential (ARP) Model' is developed by Langston and Shen (2007). It is a generic model that can be implemented on all building typologies in all countries. This model is based on a mathematical formula that estimates physical life, assesses seven obsolesce rates, calculates of useful life and adaptive reuse potential. Second, AdaptSTAR is developed by Sheila Conejos as a PhD dissertation under the supervision of Craig Langston. This model is a tool for assessing existing and future buildings' adaptive reuse potential. This tool measures the potential based on yes/no questions and ARP calculations. 


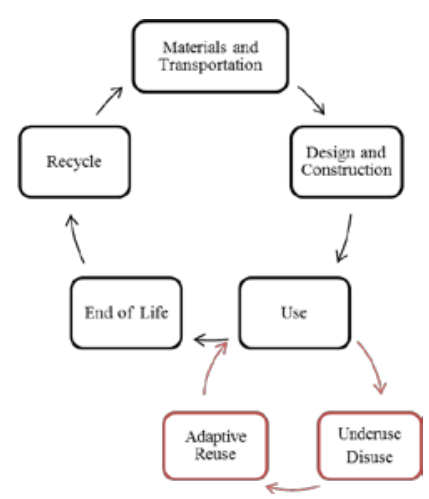

Figure 5. Adaptive reuse approach integrated sustainable building life-cycle (adapted from Building Information Modelling)
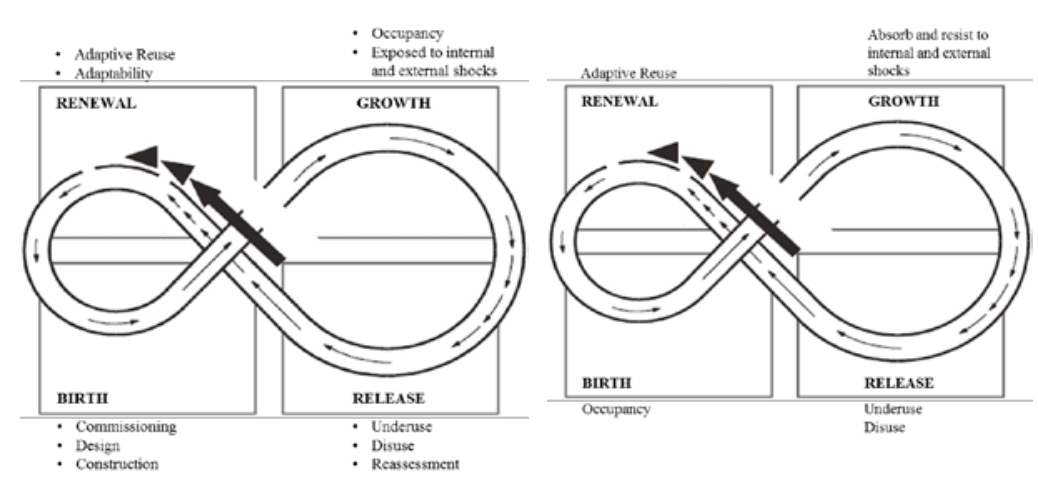

Figure 2. Building life-cycle in the context of urban resilience (adapted from Holling and Gunderson, 2002)

\section{Adaptive reuse strategies for urban resilience}

Conventional sustainable building life cycle consists of five phases: materials, construction, use, end of life, and recycle (Figure 5). It is expected that once a building reaches obsolesce or end of life (disuse), it can be demolished, materials can be salvaged or recycled. By this way raw material extraction will be minimized. On the other hand, in a resilient urban environment built fabric is designed to resist in maximum capacity and adapt to changing conditions. Once a building becomes obsolete, adaptive reuse can be put in effect. Therefore, building life cycle in urban resilience context should include adaptive reuse strategies for existing and future buildings to reach renewal stage (Figure 6). When it is represented as an adaptive cycle, building life cycle in urban resilience could be represented birth, growth, release and renewal. As it is mentioned in section 2.1, adaptive cycle (panarchy) has continuity among multiple scales. The need for adaptive reuse in a building's life cycle, therefore, can be represented as in Figure 7.

In addition, in the scope of this study AdaptSTAR tool that is based on seven obsolesces, physical, economic, functional, technological, social, legal, political, is taken as a foundation to form adaptive reuse criteria in urban resilience context. As mentioned in section 2.3, buildings could become obsolete in time. And in AdaptSTAR study, these obsolesces are addressed through a set of design qualities. Once these qualities are examined carefully, it can be found that adaptability qualities are not integrated, except functional quality. However, Nakib's (2010) study shows that integrating adaptability qualities in building can be achieved by means of socio-professional, technical, spatial and functional, economic, facade and structural criteria.

Moreover, there is a need for the use of levels concept in the adaptive reuse strategy. Built environment is directly and indirectly interconnected to sub-systems. These systems consist of independent cycles. Besides, as mentioned in section 2.2, built environment is constantly changing and these changes occur at varying time frequencies. For example, stuff could be changed monthly, but space plan could be changed in 10-15 years. Every 
level will show a change or reach an obsolescence type in varying times. Therefore, it is crucial to look at adaptive reuse in layers and timely manner. As a result, Table 3 and Table 4 are created to show which layer could benefit from specific design criterion.

Table 3. Design considerations for resilient adaptive reuse




Table 3. (Continued) Design considerations for resilient adaptive reuse

\begin{tabular}{|c|c|c|c|c|c|c|c|c|}
\hline \multicolumn{3}{|c|}{ AdaptST AR and Adaptability Guide } & \multicolumn{6}{|c|}{ LAYERS / LEVELS (Adapted from Schmidt III et.al. 2009) } \\
\hline & & Sub-criterion & Stuff & Space Plan & Services & Skin & Structure & Site \\
\hline \multirow{14}{*}{ 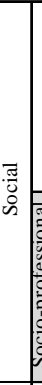 } & \multirow{14}{*}{ 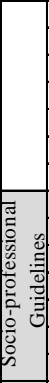 } & Image / Identity & & & & $\mathrm{x}$ & & $\mathrm{x}$ \\
\hline & & \begin{tabular}{|l|} 
Aesthetics \\
\end{tabular} & $\mathrm{x}$ & $x$ & & $\mathrm{x}$ & & $\mathrm{x}$ \\
\hline & & Landscape / Townscape & & & & & & $\mathrm{x}$ \\
\hline & & History / Authenticity & & & & & & $\mathrm{x}$ \\
\hline & & Amenity & & $\mathrm{x}$ & & & & $\mathrm{x}$ \\
\hline & & Human Scale & $\mathrm{x}$ & $\mathrm{x}$ & & & & $\mathrm{x}$ \\
\hline & & Neighborhood & & & & & & $\mathrm{x}$ \\
\hline & & Flexible thinking & & & & & & \\
\hline & & Open architecture concept & & $\mathrm{x}$ & & & & \\
\hline & & Decision making levels & $\mathrm{x}$ & $\mathrm{x}$ & $\mathrm{x}$ & $\mathrm{x}$ & $\mathrm{x}$ & $\mathrm{x}$ \\
\hline & & Encourage user involvement & $\mathrm{x}$ & $\mathrm{x}$ & $\mathrm{x}$ & & & $\mathrm{x}$ \\
\hline & & Professional interdisciplinary & $\mathrm{x}$ & $\mathrm{x}$ & $\mathrm{x}$ & $\mathrm{x}$ & $\mathrm{x}$ & $\mathrm{x}$ \\
\hline & & Active maintenance & $\mathrm{x}$ & & $\mathrm{x}$ & $\mathrm{x}$ & $\mathrm{x}$ & $\mathrm{x}$ \\
\hline & & \begin{tabular}{|l|} 
Raise awareness \\
\end{tabular} & & & & & & $\mathrm{x}$ \\
\hline \multirow{9}{*}{\multicolumn{2}{|c|}{ 㺼 }} & Standard of finish & $\mathrm{x}$ & $\mathrm{x}$ & $\mathrm{x}$ & $\mathrm{x}$ & $\mathrm{x}$ & \\
\hline & & Fire protection & $\mathrm{x}$ & & $\mathrm{x}$ & $\mathrm{x}$ & $\mathrm{x}$ & \\
\hline & & Indoor environmnetal quality & $\mathrm{x}$ & & $\mathrm{x}$ & $\mathrm{x}$ & & \\
\hline & & Occupational health\&safety & $\mathrm{x}$ & & $\mathrm{x}$ & $\mathrm{x}$ & & \\
\hline & & Security & & & $\mathrm{x}$ & & & \\
\hline & & Comfort & $\mathrm{x}$ & & $\mathrm{x}$ & $\mathrm{x}$ & $\mathrm{x}$ & \\
\hline & & Disability Access & $\mathrm{x}$ & & $\mathrm{x}$ & $\mathrm{x}$ & & \\
\hline & & Energy rating & $\mathrm{x}$ & & $\mathrm{x}$ & $\mathrm{x}$ & & \\
\hline & & Acoustics & $\mathrm{x}$ & & $\mathrm{x}$ & & & \\
\hline \multirow{7}{*}{\multicolumn{2}{|c|}{ 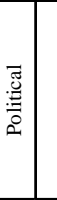 }} & Adjacent buildings & & & & & & $\mathrm{x}$ \\
\hline & & Ecological footprint & & & & & & $\mathrm{x}$ \\
\hline & & Conservation & & & & & & $\mathrm{x}$ \\
\hline & & Community interest & & & & & & $\mathrm{x}$ \\
\hline & & Urban masterplan & & & & & & $\mathrm{x}$ \\
\hline & & Zoning & & & & & & $\mathrm{x}$ \\
\hline & & Ownership & & & & & & $\mathrm{x}$ \\
\hline
\end{tabular}

\section{Conclusion}

Urban environment is affected by external and internal forces. For that reason it is under a constant change. Twentieth century's decentralization movement and rapid urbanization in cities have resulted in highly motorized and fragmented cities, the decline of town centers, and inadequate infrastructure and unplanned urbanization. As a result, cities' resilience is being questioned. In the literature it is agreed upon that existing building stock and infrastructure in cities could cater to future population wave. In this matter adaptive reuse could serve as a strategy toward urban resilience. Within the scope of this study adaptive reuse literature, case studies, definitions, principles, processes, and adaptive reuse potential assessment tools have been studied. However, an integrated approach of time and layers based approach to adaptive reuse is needed for a resilient urban environment. This theoretical study has attempted to produce adaptive reuse potential criteria for resilient cities that existing and future buildings could benefit from. Three findings could be drawn from this study. First, cities are complex systems that do not bounce back once they are destabilized. However, their 'growth' and 'release' stages could be strengthen by integrating adaptability tools and mindset into the design. Second, adaptive reuse potential could be a regularly processed health check for the buildings. Thus, changes can be responded accordingly. Third, layers and time concept should be included in adaptive reuse studies. For further research, detailed criteria for each layer (stuff, space plan, services, skin, structure, site) can be developed in detail based on building life and product life cycles. Cities could benefit from the further research for urban renewal projects. 


\section{References}

Arup International Development. (2014). City Resilience Index: City Resilience Framework. London: Ove Arup \& Partners International Limited.

Australian International Council on Monuments and Sites (ICOMOS) Burra Charter Office for Design and Architecture. (2014). Design Guidance Note 1.2.1: Adaptive Reuse. Government of South Australia. Retrieved on April 23, 2016. http://odasa.sa.gov.au/site/wp-content/uploads/2015/11/1.2.1Adaptive-Reuse-140725-FV.pdf

Barata-Salgueiro, T., \& Erkip, F. (2014). Retail planning and urban resilience-An introduction to the special issue. Cities, (36), 107-111.

Brand, S. (1995). How buildings learn: What happens after they're built. Penguin.

Bullen, P., \& Love, P. (2011). Factors influencing the adaptive re-use of buildings. Journal of Engineering, Design and Technology, 9(1), 32-46. doi:10.1108/17260531111121459

Burchell, R.W., \& Listokin, D. (1981). The adaptive reuse handbook: procedures to inventory, control, manage, and reemploy surplus municipal properties. New Brunswick, N.J.: Rutgers University, Center for Urban Policy Research.

Clark, Justine. (2013). Adaptive Reuse of Industrial Heritage: Opportunities \& Challenges.. Melbourne: Heritage Council Victoria.

Collier, Hambling, Kernaghan et al., 2014, 'Tomorrow's cities: a framework to assess urban resilience', p.79

Conejos, S. (2013). Designing for future building adaptive reuse. PhD dissertation. Bond University.

Conejos, S., \& Langston, C. (2010). Designing for future building adaptive reuse using adaptSTAR.

Davoudi, S., Brooks, E., \& Mehmood, A. (2013). Evolutionary resilience and strategies for climate adaptation. Planning Practice \& Research, 28(3), 307-322.

Dolega, L., \& Celińska-Janowicz, D. (2015). Retail resilience: A theoretical framework... for understanding town centre dynamics. Studia Regionalne I Lokalne, 60(2), 8-32. doi:10.7366/1509499526001

Folke, C., Carpenter, S., Elmqvist, T., Gunderson, L., Holling, C. S., \& Walker, B. (2002). Resilience and Sustainable Development: Building Adaptive Capacity in a World of Transformations. AMBIO: A Journal of the Human Environment, 31(5), 437-440. doi:10.1579/0044-7447-31.5.437

Folke, C., Carpenter, S., Elmqvist, T., Gunderson, L., Holling, C. S., \& Walker, B. (2002). Resilience and sustainable development: building adaptive capacity in a world of transformations. $A M B I O: A$ journal of the buman environment, 31(5), 437-440.

Habraken, J. N. (1988). The Uses of Levels. Paper presented at the Unesco Regional Seminar on Shelter for the Homeless, Seoul.

Langston, C. A. (2008). The sustainability implications of building adaptive reuse.

Langston, C., Wong, F. K., Hui, E. C., \& Shen, L. Y. (2008). Strategic assessment of building adaptive reuse opportunities in Hong Kong. Building and Environment, 43(10), 1709-1718.

Martin, R. (2012). Regional economic resilience, hysteresis and recessionary shocks, Journal of Economic Geography, 12(1), 1-32.

Nakib, F. (2010). Toward an adaptable architecture guidelines to integrate adaptability in building. In Building a Better World: CIB World Congress.

Schmidt III, R., Eguchi, T., Austin, S., and Gibb, A. (5-9 October 2009). Adaptable Futures: A 21st Century Challenge. Paper presented at the Changing Roles - New Roles, New Challenges, Noordwijk AAN ZEE, The Netherlands.

Wilson, C. (2010). Adaptive reuse of industrial buildings in Toronto, Ontario: evaluating criteria for determining building selection. 